Article

\title{
Design of a Framework for Integrating Environmentally Sustainable Design Principles and Requirements in Train Modernization Projects
}

\author{
Willem Haanstra *D, Alberto Martinetti ${ }^{\mathbb{D}}$, Jan Braaksma and Leo van Dongen $\mathbb{D}$ \\ Department of Design Production \& Management, University of Twente, De Horst 2, \\ 7522 LW Enschede, The Netherlands; a.martinetti@utwente.nl (A.M.); a.j.j.braaksma@utwente.nl (J.B.); \\ 1.a.m.vandongen@utwente.nl (L.v.D.) \\ * Correspondence: w.haanstra@utwente.nl; Tel.: +31-53-489-4063
}

Received: 3 July 2020; Accepted: 26 July 2020; Published: 28 July 2020

\begin{abstract}
Environmental sustainability is an increasingly important subject in the railway sector. Literature has revealed that transportation companies target multiple sustainability-related improvement areas and follow different strategies to improve in these. For railway operators, train modernization provides key opportunities for technical, financial, and environmental improvements halfway through the lifecycle. Using design science research, a framework was developed that is aimed at integrating sustainable design principles and sustainability-focused requirements in train modernization. The framework was tested and demonstrated by means of application to the train modernization project of an intercity train at the Nederlandse Spoorwegen in the Netherlands. The results reveal three key design mechanisms for sustainable modernization frameworks. Firstly, sustainability should be considered as early as possible in the design process. Secondly, such frameworks require efforts to simplify the way sustainability principles and impacts are considered, being careful not to oversimplify. Thirdly, the use of sustainability-focused requirements and budgets facilitate the process of prioritizing design decisions in relation to the effects they have on various environmental impacts. The design process of the framework not only provides a better understanding of the challenge of integrating sustainability, it also presents a generalizable approach that can be adapted by other organizations in the transportation sector.
\end{abstract}

Keywords: train modernization; sustainability; EcoDesign; railways; transportation; Netherlands

\section{Introduction}

Sustainable development is often considered to consist of a three-pronged fork of social sustainability (people), environmental sustainability (planet), and economic sustainability (profit), also known as the triple bottom line [1]. Stimulating the use of public transport can be seen as an important means for achieving sustainable transportation in general [2]. In this regard, a better understanding of the preferences of passengers [3] and accessibility of people to railway transportation [4] are vital prerequisites. While all three aspects of the triple bottom line are of great importance to the transportation sector, they are also fundamentally different in scope. Public transport is regarded as a significant factor towards achieving societal goals and values, particularly those related to economic and environmental issues [5].

This article focuses on the fork of environmental sustainability, which can be described as the maintenance of natural capital, the stock of environmentally provided assets that provides a flow of useful goods or services [6]. Environmental sustainability thus aims to preserve environmental assets to ensure they can still be used in the future. The transportation sector has an instrumental role to 
play in achieving the goal of environmental sustainability [7,8]. For the transportation of freight in China, the modal shift from road towards rail transportation will result in lower carbon emissions, but may also lead to higher freight transportation costs [9]. For the EU, the shift towards renewable energy land transportation would save a greater amount of fossil energy (and therefore, $\mathrm{CO}_{2}$ ) per unit of investment than air- and ship-based transport [10]. However, for the railway sector to be an environmentally sustainable option, its products and services also need to be delivered in a sustainable way. To this end, the individual actors in the railway sector are continuously looking to improve their environmental impact.

\subsection{Recent Trends in Sustainable Railway Transportation}

A review of recent literature revealed that individual railway companies target multiple sustainability-related improvement areas and follow different strategies, depending on their roles.

Firstly, current efforts of railway companies are mainly focused on reducing greenhouse gas (GHG) emissions and energy consumption. According to Lee et al. [11], in the case of rail transport, $90 \%$ of GHG emissions are associated with the use phase of the life cycle of a carriage. Many GHG reduction efforts are therefore aimed at changing the ways transportation assets are operated. The introduction of coasting in the operations of urban transport is believed to save up to $45 \%$ of energy during operation [12]. Powell et al. [13] showed that energy consumption by auxiliary systems in stabled vehicles accounts for approximately $11 \%$ of the vehicle's yearly energy consumption. Creating new operational protocols to reduce the unnecessary use of these systems during stabling hours can therefore have a significant impact on the life cycle energy use. In high speed rail (HSR), there is a large improvement possible in triple bottom line reporting practices, including a wider range of environmental sustainability factors [14]. Additionally, smart maintenance capabilities can be applied to provide environmental benefits through improved resources utilization [15].

From a design perspective, the development of new transport systems has focused on improving the energy efficiency of vehicles and their propulsion systems [16]. Common approaches for achieving higher efficiency are the use of regenerative braking, more advanced propulsion technology, and applying energy efficient driving strategies $[13,17]$. Manufacturers of rolling stock have already embraced EcoDesign in their design processes. Although the exact understanding and application of these principles varies per company, four measures appear to be universally applicable [18-20]:

1. Elimination of hazardous materials and substances;

2. Use of design for disassembly, reuse, and remanufacture;

3. Optimization for energy efficiency;

4. The use of life cycle assessment (LCA) to facilitate more environmentally sustainable decision-making.

Another observable trend is that manufacturers seek to reduce the weight of their products by using lightweight materials such as aluminum alloys and composite materials, and through the redesign of parts. These strategies are used for structural as well as interior parts of the asset $[11,21]$. This includes the reduction of glass usage, utilization of skeletal cable trays, installation of aluminum diffusers and side interior panels, and placement of lighter seats [12].

Furthermore, literature has indicated the existence of efforts that are focused around the sustainable use of natural and material resources, especially for end-of-life product phases. Manufacturers seek to minimize the number of different materials, select recycling-friendly materials, and minimize the use of hazardous substances. Literature has also noted that the product should be designed in such a manner that disassembly is made straightforward by making easily detachable connections [22]. Thus, the use of bolts and rivets, for instance, is preferred over the use of glue and other permanent connections. Moreover, adopting a modular design can reduce the need for complex modifications during the use phase. The absence of such modifications can facilitate a better end-of-life phase [23].

It is important to acknowledge the existence of a trade-off between design for enhanced recycling and for environmental sustainability in other life cycle phases [19]. The use of more advanced and 
lighter materials, for instance, increases environmental sustainability during the use phase. It can, however, also complicate proper disposal of a transport asset. Efforts are made to mitigate this problem by enabling the recycling of new materials such as carbon fiber-reinforced plastics [21]. Another important factor in optimizing the end-of-life phase is providing the right information about the asset and its parts. In the automotive sector, a system called IDIS (International Dismantling and Info System) is used to provide dismantling centers with information, such as parts lists, service handbooks, 3D drawings, and information about the materials used [18]. There is no similar system currently in use for the railway industry. The UNIFE Railway Industry Substance List can be used to identify prohibited materials, and the corresponding material declaration template can be used to provide information on materials used [24]. Unfortunately, this information is not commonly shared between companies. Therefore, material marking can improve recyclability [25].

\subsection{Problem Identification and Motivation}

Engineering and design decisions play a key role in many of the efforts described in the literature on environmentally sustainable railway transportation. In the lifecycle of any product, the earlier design stages offer the most opportunity for lifecycle improvements. However, during these early design stages, the least knowledge about the lifecycle is available [26]. Train modernization projects, therefore, represent a promising environment in which to research the relation between train design and environmental sustainability. Experience with the premodernized train provides a knowledge base that would be lacking when dealing with new product development. Furthermore, the pre- and postmodernized train designs can be directly compared, providing an opportunity for evaluating the efficacy of various design choices.

Given the wide range of potential environmental improvement principles, the first problem that passenger railway organizations face is the selection of the most appropriate environmentally sustainable design principles for specific train modernization projects. Secondly, the consideration of environmental design should also be reflected in the formulation of requirements and criteria that govern the design process of the modernized train. The integration of economic, environmental, ecological, and social factors in engineering decisions can be a complex and ill-defined endeavor because of conflicting goals and criteria [27]. As train modernization processes are already complex and constrained with respect to resources such as time, data, and knowledge, the integration of these environmental sustainability factors should be designed to be sufficiently easy-to-use to be considered in practice. In summary, this article aimed to develop a practically applicable integration approach for environmental sustainability in train modernization projects through two main activities:

1. The integration of environmentally sustainable design principles in (early) design stages;

2. The integration of environmental sustainability-focused design criteria.

\section{Materials and Methods}

\subsection{Design Science Research}

In order to explore the problem that has been stated in the introduction, this article followed a design science research (DSR) approach, in which an appropriate solution for the research question is designed. Within DSR, that which is being designed—often called the artifact-is not the only element of interest. DSR is an explicitly organized, rational, and wholly systematic approach to design, which includes not only the utilization of scientific knowledge in the development of artifacts, but can be seen as a scientific activity in itself [28]. A DSR strategy focuses on developing artifacts as well as knowledge creation, and aims to produce improvements based on a thorough understanding of problems or opportunities [29]. Therefore, the outcome of DSR is not only relevant to the practical application domain, but is also explicitly aimed at the creation of theoretical knowledge [30,31]. In case-based design research, abductive reasoning can be used to find plausible explanations for case observations [31]. 
As a research strategy, DSR can be operationalized in various ways [29]. This article built on the iterative approach suggested by Peffers et al. [32], who provided a model for producing and presenting DSR.

The DSR approach that was followed is illustrated in Figure 1. In the first phase, the main (design) research question was identified and motivated. In the next phase, the design objectives and criteria were introduced, indicating what a successful design should be able to accomplish. Subsequently, the phase of framework design and development shows the final design of the framework and the rationale behind design principles that were considered and implemented into the design. The application of the designed framework was then demonstrated and evaluated by means of a case study on train modernization at the Nederlandse Spoorwegen (NS), which has been supported by a MSc graduation project of 9 months. In conclusion, these applications were evaluated with respect to both the practical improvements they provide to NS as well as their contribution to the theoretical body of knowledge the consideration of environmental sustainability during train modernization. It should be noted that this design process is nonlinear, including an iterative design cycle that terminates when a satisfactory solution has been found.

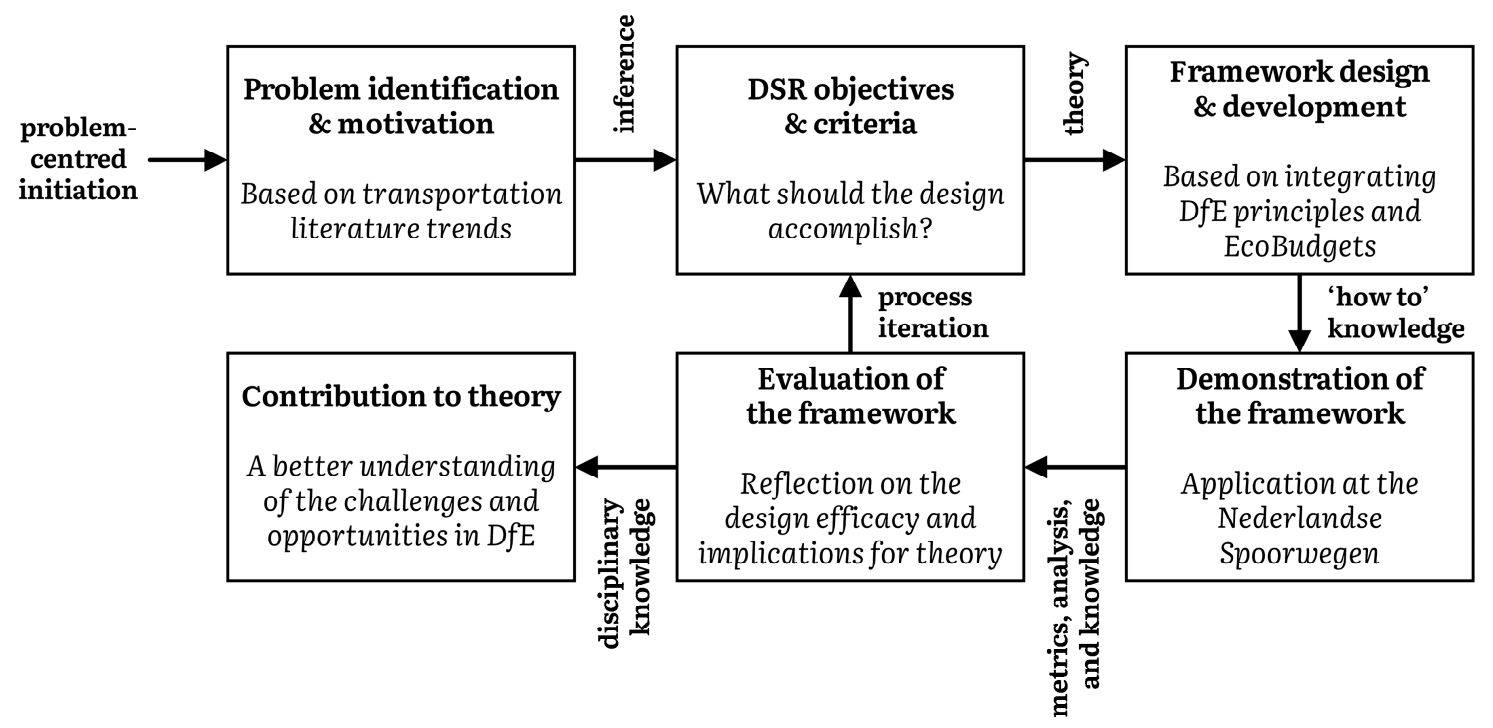

Figure 1. Design science research approach (modified from [32] to reflect its adaptation to this research).

\subsection{Design Objectives and Criteria}

The approach followed in this research was to incorporate the environmental sustainability-focused design principles and the design criteria into the design of a framework. The next step in the DSR process was to formalize what the framework should accomplish and the criteria by which its success is judged during evaluation. The design objective was twofold:

1. The framework should enable the integration of environmental sustainability in train modernization processes.

2. The framework should facilitate the discovery of improvement opportunities for environmental sustainability in train modernization.

The framework was designed for the modernization of passenger trains. The primary target audiences for the framework are the design and production management teams responsible for train modernization, as they have the most influence over design decisions that affect the train's lifespan such as energy and material use. The secondary target audience is the policy department of asset management (AM) organizations, who are required for the implementation and standardization. To evaluate to what extent the framework accomplishes the stated design goals, several design criteria have been formulated (see Table 1). The usability and function-related criteria focus on the efficacy of 
the framework with respect to the stated design goals. The process-related criteria focus in integration into practice and have therefore been formulated together with the case company, as part of a process iteration cycle of the DSR approach.

Table 1. Overview of identified design criteria.

\begin{tabular}{ccc}
\hline Topic & Criterion & Description \\
\hline Usability & U1 & $\begin{array}{r}\text { The framework should not require extensive knowledge about } \\
\text { environmental sustainability for its application }\end{array}$ \\
\cline { 2 - 3 } Process & P1 & $\begin{array}{r}\text { The framework should include environmental impact in all relevant } \\
\text { stages of train modernization projects }\end{array}$ \\
\cline { 2 - 3 } & P2 & $\begin{array}{r}\text { The integration of the framework should not significantly disrupt } \\
\text { existing decision-making processes within the organization }\end{array}$ \\
\hline Function & F1 & $\begin{array}{r}\text { Environmental sustainability should be implemented in a SMART way } \\
\text { (specific, measurable, attainable, relevant, and time-based) }\end{array}$ \\
\cline { 2 - 3 } & F2 & $\begin{array}{r}\text { The application of the framework should allow for a clear overview of } \\
\text { environmental sustainability efforts }\end{array}$ \\
\hline
\end{tabular}

\subsection{Framework Design and Development}

This section introduces existing principles that were used or adapted to create a suitable solution to the stated design problem. By discussing these solution principles separately, the core features of the framework design are made explicit and transparent. Rather than designing an entirely new environmental sustainability approach, existing literature was investigated to identify suitable approaches that can be included in, or adapted for, the framework.

\subsubsection{Overview of Existing EcoDesign Tools}

EcoDesign tools aim to develop products with their environmental performance in mind, in line with the concept of environmentally sustainable development [33]. Rossi, Germani, and Zamagni [34] found that more than a hundred EcoDesign tools, which span a wide range of applications, exist. Researchers have created different taxonomies for these tools. Rousseaux et al. [35] provided a taxonomy based on regulatory, nonregulatory normative, and nonregulatory non-normative tools, while Rossi, Germani, and Zamagni [34] distinguished between LCA tools, Computer-Aided Design (CAD) integrated tools, diagram tools, checklists and guidelines, design-for- $X$ approaches, and various methods. Bovea and Pérez-Belis [36] made a more general division into qualitative, semiqualitative, and quantitative tools.

The framework that was designed in this article drew inspiration and borrowed design principles from existing EcoDesign tools. Based on the taxonomies mentioned above, and on the literature research carried out in the introduction, Table 2 provides a selection of EcoDesign tools that were considered to be useful in the design. Each tool is briefly described, including an overview of their main advantages and disadvantages with respect to its application in train modernization. 
Table 2. Overview of reviewed EcoDesign tools (selected tools are highlighted).

\begin{tabular}{|c|c|c|c|c|}
\hline Tool & Description & Advantages & Disadvantages & Selected \\
\hline $\begin{array}{c}\text { D4S Strategy } \\
\text { Wheel and Rules } \\
\text { of Thumb [37] }\end{array}$ & $\begin{array}{l}\text { Qualitative tool used to select and visualize } \\
\text { strategies to be taken for making the design } \\
\text { more environmentally sustainable. } \\
\text { Provides a list of simple rules of thumb to } \\
\text { follow in order to ensure a more } \\
\text { environmentally sustainable design, } \\
\text { providing practical guidance for improving } \\
\text { the product based on these strategies. }\end{array}$ & $\begin{array}{l}- \text { Ease of use } \\
- \text { Clear } \\
\text { visualization of } \\
\text { what path to take } \\
\text {-Provides practical } \\
\text { advice }\end{array}$ & $\begin{array}{l}\text { - No way to } \\
\text { measure the } \\
\text { product } \\
\text { - Only provides } \\
\text { general guidance }\end{array}$ & $\begin{array}{l}\text { No, the more } \\
\text { specific guidance of } \\
\text { Ten Golden Rules } \\
\text { was preferred }\end{array}$ \\
\hline MECO Matrix [38] & $\begin{array}{l}\text { Simple qualitative assessment based on } \\
\text { materials, energy, chemicals, and other } \\
\text { aspects in order to compare the impact of } \\
\text { two design alternatives during the life } \\
\text { cycle. }\end{array}$ & $\begin{array}{l}\text { - Ease of use } \\
\text { - Forces designers } \\
\text { to think about a } \\
\text { range of different } \\
\text { issues } \\
\text { - Provides a means } \\
\text { for comparison }\end{array}$ & $\begin{array}{l}\text { - Very general } \\
\text { - Does not suggest } \\
\text { solutions }\end{array}$ & $\begin{array}{l}\text { No, due to lack of } \\
\text { solution focus }\end{array}$ \\
\hline $\begin{array}{c}\text { Ten Golden Rules } \\
\text { [39] }\end{array}$ & $\begin{array}{l}\text { Ten qualitative rules that can be used as } \\
\text { guidance for making the overall product } \\
\text { design more environmentally sustainable. }\end{array}$ & $\begin{array}{l}\text { - Ease of use } \\
\text { - Can promote } \\
\text { environmental } \\
\text { sustainability } \\
\text { awareness for } \\
\text { employees }\end{array}$ & $\begin{array}{l}\text { - Very general } \\
\text { - Some rules can be } \\
\text { contradictory }\end{array}$ & Yes \\
\hline $\begin{array}{l}\text { Eco-functional } \\
\text { Matrix [40] }\end{array}$ & $\begin{array}{l}\text { Semiqualitative linking technique based on } \\
\text { QFD using a matrix that links functional } \\
\text { and environmental aspects of a product. } \\
\text { Identifies which aspects are important for } \\
\text { the product and which aspects correlate in } \\
\text { order to highlight critical points. }\end{array}$ & $\begin{array}{l}\text { - Combines } \\
\text { functionality with } \\
\text { environmental } \\
\text { performance } \\
\text { - Clearly links } \\
\text { different issues }\end{array}$ & $\begin{array}{l}\text { - Issues are } \\
\text { considered at a } \\
\text { high level; outcome } \\
\text { for a train is always } \\
\text { similar } \\
\text { - Does not suggest } \\
\text { solutions }\end{array}$ & $\begin{array}{l}\text { No, due to high } \\
\text { abstraction level of } \\
\text { application }\end{array}$ \\
\hline SCPD [41] & $\begin{array}{l}\text { Semiqualitative checklist for } \\
\text { environmentally sustainable product } \\
\text { design consisting of } 49 \text { yes/no questions } \\
\text { that encourage engineers to think about the } \\
\text { whole life cycle. Generates a task list of } \\
\text { follow-up actions based on the answers. }\end{array}$ & $\begin{array}{l}\text { - Possibility to } \\
\text { score and compare } \\
\text { products } \\
\text { - Generates clear } \\
\text { task list of } \\
\text { follow-up actions } \\
\text { - Dialogic } \\
\text { approach improves } \\
\text { communication }\end{array}$ & $\begin{array}{l}\text { - Environmental } \\
\text { sustainability } \\
\text { expertise required } \\
\text { to reach full } \\
\text { potential }\end{array}$ & $\begin{array}{l}\text { No, based on } \\
\text { expertise } \\
\text { requirement }\end{array}$ \\
\hline $\begin{array}{c}\text { Design for } \\
\text { Environment } \\
\text { Matrix (DfE) [42] }\end{array}$ & $\begin{array}{l}\text { Semiqualitative matrix with questions } \\
\text { about various environmental factors } \\
\text { grouped according to life cycle stage. Each } \\
\text { cell consists of one or more questions and is } \\
\text { worth } 5 \text { points. Answering all questions } \\
\text { provides a score for each issue and makes it } \\
\text { possible to compare products. }\end{array}$ & $\begin{array}{l}\text { - Scores products } \\
\text { without needing } \\
\text { very specific } \\
\text { information } \\
\text { - Questions can } \\
\text { raise awareness of } \\
\text { environmental } \\
\text { sustainability } \\
\text { issues }\end{array}$ & $\begin{array}{l}\text { - Questions can be } \\
\text { hard to answer at } \\
\text { the train level } \\
\text { (but is suitable for } \\
\text { subsystem level) }\end{array}$ & Yes \\
\hline ReSICLED [43] & $\begin{array}{l}\text { Quantitative assessment of the } \\
\text { recoverability of a product based on the } \\
\text { weight and economic and environmental } \\
\text { costs or benefits. Accounts for both } \\
\text { material attributes and product design } \\
\text { characteristics. }\end{array}$ & $\begin{array}{l}\text { - Quantitative } \\
\text { assessment makes } \\
\text { comparison easy } \\
\text { - Accurate } \\
\text { description of } \\
\text { recyclability }\end{array}$ & $\begin{array}{l}\text { - Complexity } \\
\text { - Involves a lot of } \\
\text { data gathering and } \\
\text { calculations } \\
\text { - Only takes into } \\
\text { account the EOL } \\
\text { stage }\end{array}$ & $\begin{array}{l}\text { No, due to } \\
\text { limitations in } \\
\text { usability }\end{array}$ \\
\hline $\begin{array}{l}\text { Simple } \\
\text { Eco-indicators [44] }\end{array}$ & $\begin{array}{l}\text { Set of simplified quantitative indicators of } \\
\text { the environmental attributes of a product. } \\
\text { Easy to calculate figures that correlate with } \\
\text { indicators of a more complicated LCA. }\end{array}$ & $\begin{array}{l}\text { - Easy method for } \\
\text { quantifying } \\
\text { product } \\
\text { characteristics } \\
\text { - Can be used to } \\
\text { compare design } \\
\text { alternatives }\end{array}$ & $\begin{array}{l}\text { - } \\
\text { list of indicators } \\
\text { - May induce } \\
\text { oversimplification } \\
\text { when applied at } \\
\text { train level }\end{array}$ & $\begin{array}{l}\text { No, DfE matrix } \\
\text { was deemed more } \\
\text { usable for the } \\
\text { framework }\end{array}$ \\
\hline EcoPaS [45] & $\begin{array}{l}\text { Quantitative model for calculating } \\
\text { environmental impact using basic product } \\
\text { parameters. So-called eCERs (eco-cost } \\
\text { estimating relationships) are used to link } \\
\text { basic parameters to environmental impact. }\end{array}$ & $\begin{array}{l}\text { - Comprehensive } \\
\text { quantification of } \\
\text { product } \\
\text { characteristics } \\
\text { based on available } \\
\text { information } \\
\text { - Can be used to } \\
\text { compare design } \\
\text { alternatives }\end{array}$ & $\begin{array}{l}\text { - eCERs have to be } \\
\text { defined for each } \\
\text { system } \\
\text { - Realistic } \\
\text { representation of a } \\
\text { train is challenging }\end{array}$ & $\begin{array}{l}\text { No, due to } \\
\text { limitations with } \\
\text { usability }\end{array}$ \\
\hline
\end{tabular}




\subsubsection{Selected EcoDesign Tools}

From the list of potential EcoDesign tools that align for the stated design goals, a combination of two tools were deemed to best fit the stated design criteria and the application context at the case company. This led to a selection of two applicable EcoDesign tools that were included in the framework: the 10 Golden Rules [39] and the Design for Environment (DfE) matrix [42]. An important consideration in this selection was that the existing train modernization process would not be significantly disrupted by the inclusion of the DfE principles (criterion P2). This was achieved by aligning the application of existing EcoDesign tools with the basic structure of a train modernization process and including only instruments that are easy to use and applicable in that context. This was done in collaboration with the case company. The framework should also allow for means of evaluating the efficacy of the design choices (criterion F2). A combination of accessible qualitative and (semi-)quantitative elements allows for the inclusion of generic design guidelines as well as a way to measure the efficacy of the proposed solutions, while still ensuring usability (criterion U1).

Life cycle assessment was not deemed suitable for the framework for two main reasons. Firstly, LCA is usually conducted by environmental specialists and rarely by designers during the design phase [46]. Secondly, the application at the design stage can be difficult because of its laborious, expansive, and time-consuming nature [47]. Streamlined variants of LCA may be able to provide essentially the same type of results as a detailed LCA in a more superficial manner [48], but less complex methods such as simple eco-indicators were already deemed unsuited with respect to usability (criterion U1).

\section{Results}

\subsection{EcoDesign Framework for Train Modernization}

The developed framework integrated modified versions of two existing EcoDesign tools and their principles into train modernization processes, as well as providing environmental sustainability-related design requirements (see Figure 2). This integration framework focuses on the earliest train modernization stages where the engineering freedom, and therefore the potential for sustainability improvements, is highest (criterion P1).

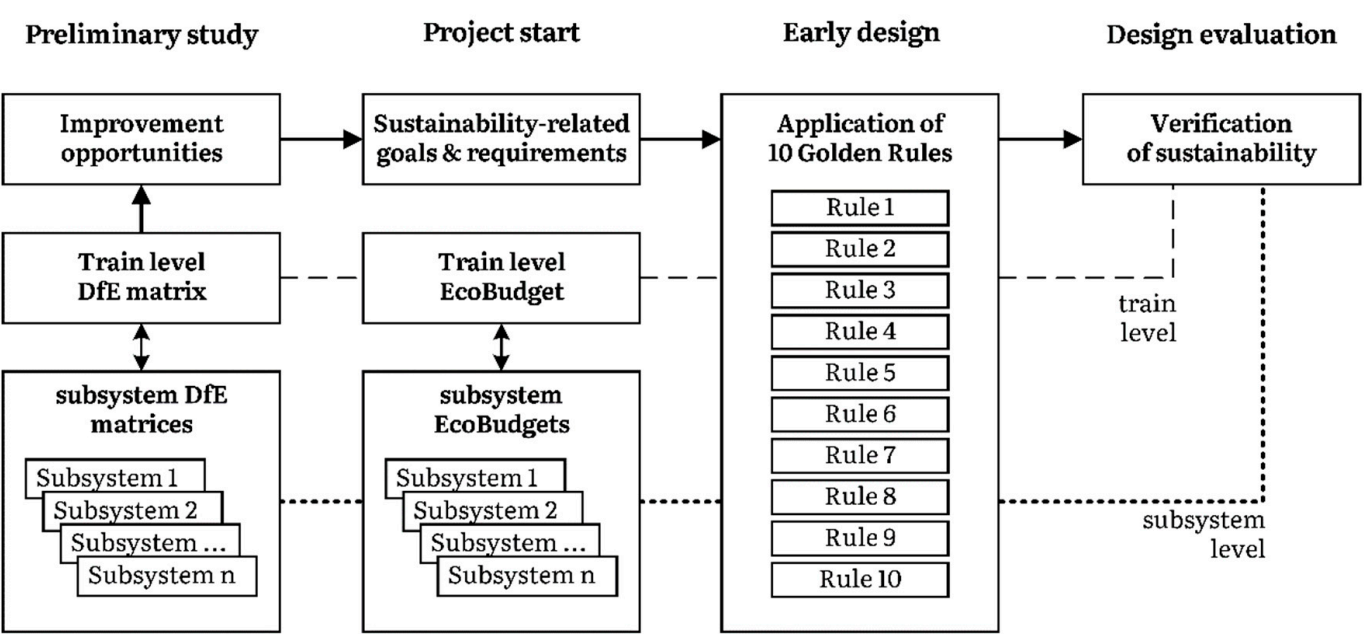

Figure 2. EcoDesign framework for train modernization.

\subsubsection{Stage 1: Preliminary Study}

In the early stages of train modernization projects, the Design for Environment (DfE) matrix [42] is adapted as the starting point for a kick-off brainstorm session by quickly determining a semiquantitative improvement profile of the premodernized train and its subsystems. Each matrix consists of an axis 
indicating multiple lifecycle stages and an axis illustrating relevant environmental concerns. Each of the cells in the matrix is assigned a number of qualitative questions. These questions are answered with 'Yes', 'No', or 'Not Applicable'. These answers can then be used to semiquantitatively assess specific designs according to different categories of environmental impact. The questions contained in the DfE matrix may be too general, making them difficult to answer at the train level. However, it is possible to apply DfE matrices to each of the subsystems and aggregating the scores to the level of the entire train.

\subsubsection{Stage 2: Project Start}

The outcome of the DfE matrix can not only be used to evaluate an environmental profile of the existing train, but also for setting meaningful, yet accessible, goals and requirements for the modernized train design (criterion P3). These requirements can take both qualitative and quantitative forms. For example, qualitative goals can be based on the answers resulting from the DfE matrix of the existing train. Other, more specific, goals can also be included in this phase, for example quantifiable performance metrics such as energy use, GHG emissions, or recycled material content. These requirements can be viewed as environmental sustainability budgets. The selection of requirements and budgets depends on the subject of study, the environmental issues that the organization intends to address, and the targets set for these efforts.

\subsubsection{Stage 3: Early Design}

In the previous two stages, the baseline environmental performance of the old train and the environmental sustainability targets for the modernized train were established. In order to support the creative process of developing new design options, the golden rules of EcoDesign [39] can be used to guide earlier development stages (Table 3). Even though these 10 rules are rather generic in their formulation and can be contradictory, they are also easy to use, promote awareness of environmental sustainability, and focus efforts towards likely effective improvement areas without requiring environmental sustainability-related expertise (criterion U1). When combined with the DfE matrix, these 10 rules can be used to both structure and prioritize the efforts taken to improve different environmental sustainability measures (criterion F1). These efforts should result in a new design for the modernized train and its components in which specific environmentally sustainable design principles are included.

Table 3. 10 Golden Rules of EcoDesign [39].

\begin{tabular}{cl}
\hline Rule & \multicolumn{1}{c}{ Description } \\
\hline $\mathbf{1}$ & Do not use toxic substances and utilize closed loops for necessary but toxic ones \\
\hline $\mathbf{2}$ & $\begin{array}{l}\text { Minimize energy and resource consumption in the production phase and transport } \\
\text { through improved housekeeping }\end{array}$ \\
\hline $\mathbf{3}$ & $\begin{array}{l}\text { Use structural features and high-quality materials to minimize weight in products. If such } \\
\text { choices do not interfere with necessary flexibility, impact strength, or other functional } \\
\text { priorities }\end{array}$ \\
\hline $\mathbf{4}$ & $\begin{array}{l}\text { Minimize energy and resource consumption in the usage phase, especially for products } \\
\text { with the most significant aspects in the usage phase }\end{array}$ \\
\hline $\mathbf{6}$ & $\begin{array}{l}\text { Promote repair and upgrading, especially for system-dependent products. (e.g., cell } \\
\text { phones, computers, and CD players) }\end{array}$ \\
\hline $\mathbf{7}$ & $\begin{array}{l}\text { Promote long life, especially for products with significant environmental aspects outside of } \\
\text { the usage phase }\end{array}$ \\
\hline & $\begin{array}{l}\text { Invest in better materials, surface treatments, or structural arrangements to protect } \\
\text { products from dirt, corrosion, and wear, thereby ensuring reduced maintenance and longer } \\
\text { product life }\end{array}$ \\
\hline
\end{tabular}


Table 3. Cont.

\begin{tabular}{cl}
\hline Rule & \multicolumn{1}{c}{ Description } \\
\hline $\mathbf{8}$ & $\begin{array}{l}\text { Prearrange upgrading, repair, and recycling through access ability, labelling, modules, } \\
\text { breaking points, and manuals }\end{array}$ \\
\hline $\mathbf{9}$ & $\begin{array}{l}\text { Promote upgrading, repair, and recycling by using few, simple, recycled, not blended } \\
\text { materials and no alloys }\end{array}$ \\
\hline $\mathbf{1 0}$ & $\begin{array}{l}\text { Use as few joining elements as possible and use screws, adhesives, welding, snap fits, } \\
\text { geometric locking, etc. according to the life cycle scenario }\end{array}$ \\
\hline
\end{tabular}

\subsubsection{Stage 4: Design Evaluation}

The results from the previous modernization stages are verified during the design evaluation stage. When all environmental performances of the modernized train design(s) are calculated, the scores can be compared against the previously stated qualitative and quantitative environmental requirements. Alternatively, different design options can be compared against each other. As design processes are iterative in nature, part of the evaluation is expected to be concurrent with the earlier design stages. A final evaluation of the design of the entire modernized train (including all of its subsystems) can be used to determine the overall environmental sustainability score and whether or not the environmental sustainability goals have been achieved (criterion F2).

\subsection{Application Context}

As mentioned in the abstract, the designed framework was applied using a real-world train modernization project at Nederlandse Spoorwegen (NS) (translated: Netherlands Railways). This not only allowed for an authentic demonstration of the designed framework, but also fostered the development of a thorough understanding of the challenges of integrating environmental sustainability in train modernization processes.

As the main passenger operator on the railway network in the Netherlands, NS plays a vital role in providing sustainable mobility in the country. NS is constantly striving to make their operations more sustainable. A notable achievement on the environmental sustainability front on the part of the organization is the switch to using $100 \%$ renewable energy to power the trains.

NS Train Modernization (NSTM) is the branch of NS in charge of the complete overhaul of part of the fleet of rolling stock. Its long-term vision is to improve the environmental sustainability of the rolling stock that needs to be modernized in order to face the second part of its useful life. At NSTM, different phases in the train modernization process are distinguished. As the environmental sustainability of the train series is mainly determined by the earlier design decisions, the case study focuses on the first four train modernization process stages, up to and including the evaluation of early design (see Figure 3).

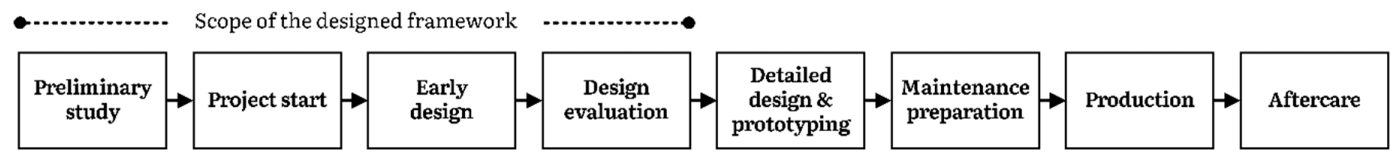

Figure 3. Stages of train modernization at Nederlandse Spoorwegen Train Modernization (NSTM).

The VIRM (acronym for lengthened interregional rolling stock in Dutch), is a double decker train (see Figure 4) that currently forms the backbone of the intercity fleet of NS. This train series was taken into service at three different points in time. The first in 1994, the second in 2003 and the third in the year 2008, resulting in the technically identical subseries VIMRm1, VIRMm2/3, and VIRMm4 respectively. 


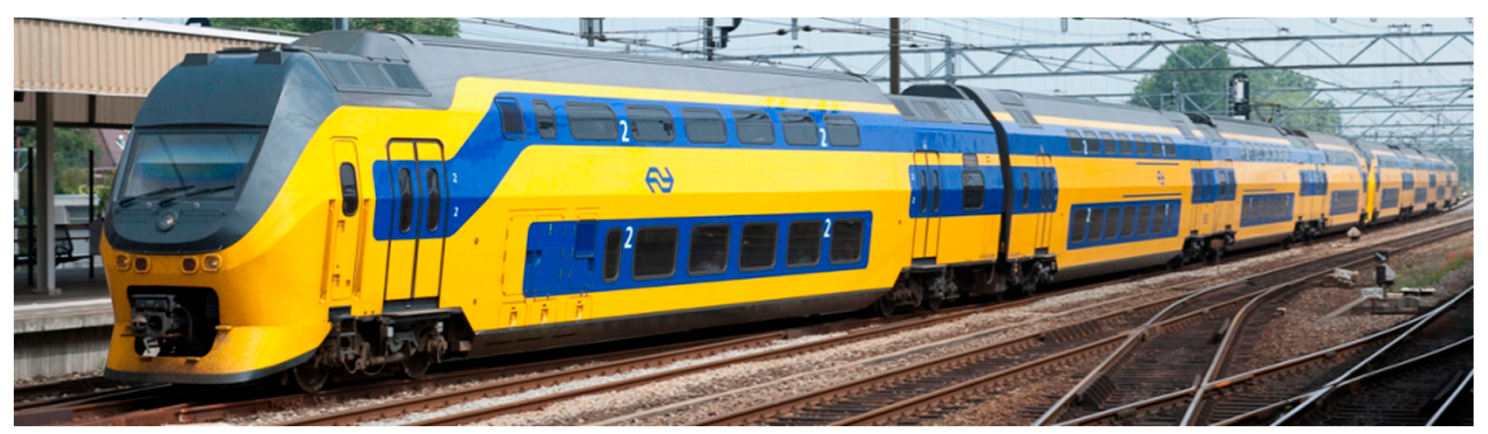

Figure 4. VIRM train before modernization.

The first of these subseries (VIRMm1) has already been through a modernization stage. The VIRMm $2 / 3$ builds on the already completed modernization process of the VIRMm 1 subseries. The specifications and design of this project were reused in the modernization of the VIRMm2/3, unless there were clear reasons to deviate from this earlier design. The VIRMm2/3 modernization project aims to revise and modernize the VIRMm2/3 train for another 18 years of use and consists of revising most technical systems, installing a new interior, and updating the exterior. An additional target of NSTM is to improve the environmental sustainability profile beyond that of the VIRMm1 project.

Given the reapplication of many of the design decisions of the original VIRMm1 project, the technical scope of the VIRMm2/3 modernization project was already reduced to a limited set of subsystems. Notable exceptions to this are the full replacement of the systems of all heating and air conditioning (HVAC) units (for passengers as well as train drivers) and the redesign of the coach's power supply. Furthermore, the toilets/sanitary systems will be modernized, as well as the catering/galley section. The interior of the floors, stairways, vestibules, and drivers' cabin are also being updated, alongside objects such as seats, tables, garbage bins, coat hooks, partition walls, luggage racks, ceiling panels, and side panels. Other systems are excluded from our scope as these are not likely to be significantly altered in the modernization process.

\subsection{Demonstration of the Design-for-Environment Framework}

\subsubsection{Stage 1: Preliminary Study}

During the preliminary study stage, the DfE matrices for the original (premodernized) VIRMm2/3 train and all of the relevant subsystems were assigned scores using the responses to a structured interview with the members of the NSTM team and a Sustainable Business manager. A comprehensive list of the environmental sustainability questions used in the matrix can be found in Appendix A. Instead of using the matrix of Yarwood and Eagan [42], a DfE matrix modified for NSTM was used, allowing for the inclusion of the environmental sustainability themes and issues that were relevant to NSTM. The environmental score for the VIRMm2/3 was defined by converting the 'yes' and 'no' answers of the DfE matrix into a percentage score for each of the subsystems. 'N/A' was used to indicate questions that did not have a clear yes or no answer in the assessment of the initial score. These answers were then aggregated to the train level, calculating an overall score for each environmental sustainability issue and theme. The resulting filled-in DfE matrix can be found in Table 4 . 
Table 4. Design for Environment (DfE) matrix showing the initial overall score for all subsystems of the (premodernized) VIRMm2/3.

\begin{tabular}{|c|c|c|c|c|c|c|c|c|c|c|c|c|}
\hline \multirow{2}{*}{ Theme } & \multirow{2}{*}{ Issue } & & \multicolumn{8}{|c|}{ Questions (See Appendix A) } & \multicolumn{2}{|c|}{ Score } \\
\hline & & & 1 & 2 & 3 & 4 & 5 & 6 & 7 & 8 & Issue & Theme \\
\hline \multirow{2}{*}{$\begin{array}{l}\text { Energy, } \mathrm{CO}_{2} \\
\text { and climate }\end{array}$} & Energy use & $\mathrm{A}$ & $20 \%$ & $10 \%$ & $38 \%$ & $20 \%$ & $56 \%$ & $100 \%$ & $0 \%$ & $86 \%$ & $41 \%$ & \multirow[b]{2}{*}{$41 \%$} \\
\hline & $\begin{array}{l}\text { Embedded GHG } \\
\text { emissions }\end{array}$ & B & N/A & N/A & & & & & & & N/A & \\
\hline \multirow{3}{*}{ Circularity } & Material use & $\mathrm{C}$ & $70 \%$ & N/A & $\mathrm{N} / \mathrm{A}$ & N/A & N/A & & & & $70 \%$ & \multirow{3}{*}{$70 \%$} \\
\hline & Recycled material & $\mathrm{D}$ & N/A & & & & & & & & N/A & \\
\hline & $\begin{array}{l}\text { Recyclability of new } \\
\text { components }\end{array}$ & E & N/A & N/A & N/A & N/A & N/A & $\mathrm{N} / \mathrm{A}$ & N/A & & N/A & \\
\hline \multirow{2}{*}{ Maintainability } & $\begin{array}{l}\text { Efficiency in } \\
\text { maintenance }\end{array}$ & F & $100 \%$ & $60 \%$ & $80 \%$ & $20 \%$ & $100 \%$ & $80 \%$ & & & $73 \%$ & \multirow[b]{2}{*}{$71 \%$} \\
\hline & $\begin{array}{l}\text { Hazardous } \\
\text { substances in } \\
\text { maintenance }\end{array}$ & G & $50 \%$ & $40 \%$ & $90 \%$ & $100 \%$ & $60 \%$ & & & & $68 \%$ & \\
\hline Toxicity & $\begin{array}{l}\text { Use of hazardous } \\
\text { substances }\end{array}$ & $\mathrm{H}$ & N/A & N/A & $\mathrm{N} / \mathrm{A}$ & $83 \%$ & $78 \%$ & $0 \%$ & & & $54 \%$ & $54 \%$ \\
\hline \multirow{3}{*}{$\begin{array}{l}\text { Overhaul } \\
\text { process }\end{array}$} & $\begin{array}{l}\text { Sustainable } \\
\text { disassembly }\end{array}$ & I & $0 \%$ & $100 \%$ & & & & & & & $50 \%$ & \multirow{3}{*}{$41 \%$} \\
\hline & $\begin{array}{l}\text { Sustainable } \\
\text { manufacturing }\end{array}$ & $\mathrm{J}$ & $0 \%$ & $0 \%$ & $100 \%$ & $100 \%$ & $0 \%$ & & & & $40 \%$ & \\
\hline & Sustainable logistics & K & $0 \%$ & $100 \%$ & $0 \%$ & $100 \%$ & $0 \%$ & $0 \%$ & & & $33 \%$ & \\
\hline Experience & $\begin{array}{l}\text { Customer } \\
\text { experience }\end{array}$ & $\mathrm{L}$ & $0 \%$ & $0 \%$ & $0 \%$ & $0 \%$ & $0 \%$ & & & & $0 \%$ & $0 \%$ \\
\hline
\end{tabular}

Based on the outcome of the DfE matrix, multiple improvement opportunities could be identified. For example, the theme of 'energy, $\mathrm{CO}_{2}$, and climate' revealed multiple opportunities for the application of lightweight materials and structural reinforcements.

\subsubsection{Stage 2: Project Start}

Based on the issues identified and evaluated in the first stage, it was possible to formulate environmental sustainability-related improvement objectives and requirements, based on the outcome of the DfE matrix of Table 4. For each of the scores an indication is provided regarding whether a measurable improvement is required (indicated by 'yes') or not required (indicated by 'no') in Table 5. This is done using the same list of questions used in the first stage. Even the 'N/A' questions of the initial assessment (Table 4) could be answered in a 'yes or no' manner, as the questions of Table 5 are now answered with the aim of indicating improvement areas.

Alongside the binary goals related to the DfE questions and scores, specific environmental sustainability-related requirements were also formulated together with a requirements manager of NSTM. To distinguish these environmental sustainability-focused requirements from other modernization requirements, they will be referred to as the EcoBudget. This EcoBudget (Table 6) is quantitative in nature and are based on the baseline average lifecycle profile of the VIRMm1 train, including all subsystems. The EcoBudget is used to indicate the minimum level of performance required for each environmental theme. NSTM opted not to use a minimum requirement for recycled material, hence the value of zero in that category. 
Table 5. DfE matrix indicating improvement goals for the modernized VIRMm2/3 train.

\begin{tabular}{|c|c|c|c|c|c|c|c|c|c|c|}
\hline \multirow{2}{*}{ Theme } & \multirow{2}{*}{ Issue } & & \multicolumn{8}{|c|}{ Questions (see Appendix A) } \\
\hline & & & 1 & 2 & 3 & 4 & 5 & 6 & 7 & 8 \\
\hline \multirow{2}{*}{$\begin{array}{l}\text { Energy, } \mathrm{CO}_{2} \text { and } \\
\text { climate }\end{array}$} & Energy use & A & yes & yes & yes & no & no & No & yes & yes \\
\hline & $\begin{array}{l}\text { Embedded GHG } \\
\text { emissions }\end{array}$ & B & yes & yes & & & & & & \\
\hline \multirow{3}{*}{ Circularity } & Material use & C & yes & yes & no & yes & no & & & \\
\hline & Recycled material & $\mathrm{D}$ & yes & & & & & & & \\
\hline & $\begin{array}{l}\text { Recyclability of new } \\
\text { components }\end{array}$ & E & yes & no & yes & yes & yes & yes & yes & \\
\hline \multirow[b]{2}{*}{ Maintainability } & Efficiency in maintenance & $\mathrm{F}$ & no & no & no & no & no & yes & & \\
\hline & $\begin{array}{l}\text { Hazardous substances in } \\
\text { maintenance }\end{array}$ & G & no & yes & no & no & yes & & & \\
\hline Toxicity & $\begin{array}{l}\text { Use of hazardous } \\
\text { substances }\end{array}$ & $\mathrm{H}$ & no & no & no & no & yes & no & & \\
\hline \multirow{3}{*}{ Overhaul process } & Sustainable disassembly & I & yes & no & & & & & & \\
\hline & $\begin{array}{l}\text { Sustainable } \\
\text { manufacturing }\end{array}$ & $\mathrm{J}$ & yes & no & no & no & yes & & & \\
\hline & Sustainable logistics & K & no & no & no & no & no & yes & & \\
\hline Experience & Customer experience & $\mathrm{L}$ & yes & yes & yes & yes & & & & \\
\hline
\end{tabular}

Table 6. The quantitative requirements of the EcoBudget.

\begin{tabular}{clll}
\hline \multicolumn{1}{c}{ Theme } & \multicolumn{1}{c}{ Requirement } & \multicolumn{1}{c}{ Budget } & \multicolumn{1}{c}{ Unit } \\
\hline \multirow{2}{*}{ Energy, $\mathbf{C O}_{2}$, and climate } & Auxiliary energy & 22.436 & $\mathrm{kWh} /$ year \\
\cline { 2 - 4 } & Embedded GHG emissions & 56.807 & $\mathrm{~kg} \mathrm{CO}$-eq. \\
\hline \multirow{2}{*}{ Circularity } & Material use & 103.837 & $\mathrm{~kg} \mathrm{Fe}$-eq. \\
\cline { 2 - 4 } & Recycled material & 0 & $\mathrm{~kg} \mathrm{Fe}$-eq. \\
\cline { 2 - 4 } & Recyclability & 93.453 & $\mathrm{~kg} \mathrm{Fe}$-eq. \\
\hline
\end{tabular}

\subsubsection{Stage 3: Early Design}

During the early design phases of the train modernization project, compliance with the various environmental sustainability requirements is tested during the various reviews. The other main purpose of the framework in these phases is to guide the smaller design choices, which is done by means of the application of the 10 Golden Rules of EcoDesign created by Luttrop and Lagerstedt [39]. As indicated earlier, not all of these rules may be applicable and some might even be contradictory. However, the quantitative requirements established in the previous two phases of the framework help guide the selection of the rules that best fit the design goals and requirements.

To demonstrate the application of the framework during this stage, an example of one of these smaller design choices is provided by the selection of seating options as part of the interior design. Together with NSTM, the EcoBudgets and the ' 10 Golden rules' for the interior design were discussed, leading to the identification of reducing the weight (rule 4) of the seats in the train as a promising design direction. Two seating options were considered: a lighter weight seat $A$ or seat $B$, which is similarly shaped as seat A, but has a different material composition. As indicated in Figure 5, the EcoBudget impact for the two seating options differ from each other. Seat A has a lighter weight, but contains more nonrenewable materials and has a higher embedded GHG impact than seat A. As neither option fully outscores the other, preference depends on how the seats contribute to the overall environmental budget scores. Seat A was eventually chosen as it best fit the overall requirements for the design for the modernized VIRMm2/3 train. 


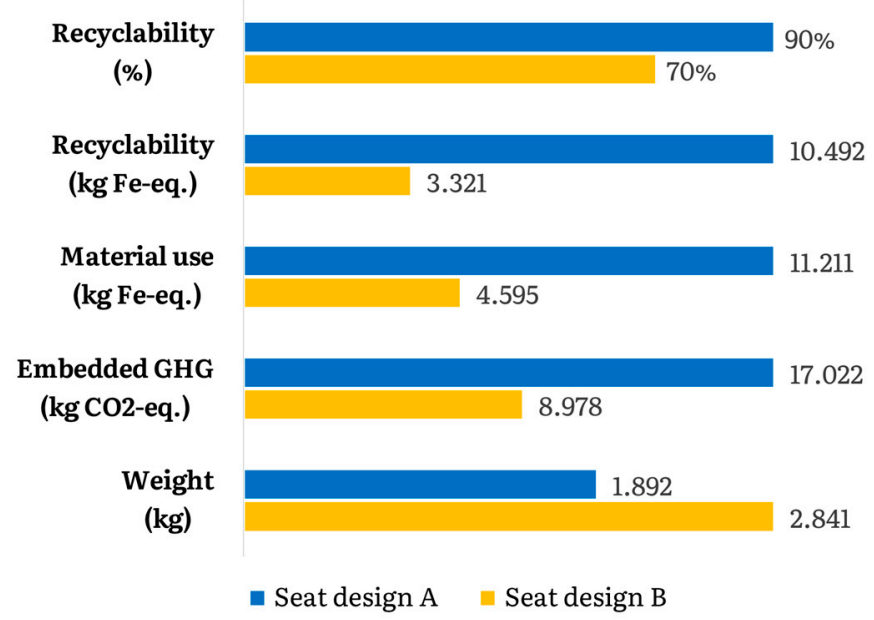

Figure 5. EcoBudget impacts of seating options.

\subsubsection{Stage 4: Design Evaluation}

The overall effectiveness of using the DfE matrix and environmental sustainability budgets was discussed in a general session, which included the project manager, the requirements manager, and the senior engineer of the train modernization process. Finding sufficient data for the existing train and the modernization options was challenging, taking up additional resources in the modernization process. In our application, not all subsystems could be included in the overall budget score for the modernized train for this reason. However, the EcoBudget score for the interior of the train could be determined (see Table 7). The EcoBudget for the entire train can be built up by aggregating the scores of the individual subsystems. Even though this application was not complete, the modernization staff agreed that the inclusion of this framework was useful, as it helped to systematically integrate environmental sustainability into the existing modernization process.

Table 7. EcoBudget score for the interior of the train.

\begin{tabular}{|c|c|c|c|c|c|}
\hline & \multicolumn{2}{|c|}{ Energy, $\mathrm{CO}_{2}$ and Climate } & \multicolumn{3}{|c|}{ Circularity } \\
\hline & $\begin{array}{c}\text { Auxiliary } \\
\text { Energy } \\
\text { (kWh/year) }\end{array}$ & 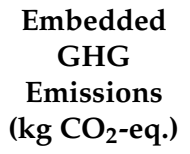 & $\begin{array}{l}\text { Material Use } \\
\text { (kg Fe-eq.) }\end{array}$ & $\begin{array}{c}\text { Recycled } \\
\text { Material } \\
\text { (kg Fe-eq.) }\end{array}$ & $\begin{array}{l}\text { Recyclability } \\
\text { (kg Fe-eq.) }\end{array}$ \\
\hline Total budgets: & 0 & 36.717 & 25.061 & 0 & 22.555 \\
\hline $\begin{array}{l}\text { Floors and } \\
\text { stairways, } \\
\text { vestibules }\end{array}$ & 0 & 9.989 & 7.150 & 0 & 6.435 \\
\hline Compartments & 0 & 17.861 & 12.675 & 0 & 11.408 \\
\hline $\begin{array}{c}\text { Toilet/sanitary } \\
\text { system }\end{array}$ & - & 2.864 & 1.845 & 0 & 1.661 \\
\hline Catering/galley & - & - & - & 0 & - \\
\hline HVAC & 117.445 & 6.002 & 3.391 & 0 & 3.052 \\
\hline Driver's cab & - & - & - & 0 & - \\
\hline
\end{tabular}

\section{Discussion}

The topic of sustainability demands increasingly more attention from companies. Many of the actions taken by industry are not a response to government actions, but are derived from actions taken in industry itself, resulting from a form of peer pressure [49]. It is through these concrete actions that the railway sector can improve its environmental sustainability from the bottom-up. For railway 
operators, actions to improve environmental sustainability can be traced back to the designs of their train series, which determine a large extent of environmental impact during production, operation, maintenance, and end-of-life.

To support this improvement process as early as possible, an EcoDesign framework was developed. Even though the framework was intended as a proof-in-concept, its application in a real-world setting and subsequent evaluation does allow for a rich reflection on its underlying principles, efficacy, and relevant considerations that need to be taken into account in the development of new approaches. The objectives for the framework were that it should enable the integration of environmental sustainability in train modernization processes (design goal 1) and that it should facilitate the discovery of improvement opportunities for environmental sustainability in train modernization (design goal 2). After considering a number of design principles and going through multiple design iterations, a suitable solution was found in the form of the EcoDesign framework for train modernization. The demonstration of the framework at NSTM illustrated that the framework was both feasible and useful for incorporating environmental sustainability in train modernization projects. Besides the creation of the framework as an artifact, the DSR approach also resulted in the development of a better understanding of the challenges and opportunities in the application of Design for Environment principles. Using abductive reasoning, plausible explanations for case observations are discussed by reflecting on the design of the framework and its application in the real-world context at NSTM.

Three main mechanisms appear to best explain which opportunities and limitations are addressed by the final design of the framework. The first mechanism consists of the consideration of environmental sustainability in the earliest phases possible. In these early stages, the design decisions are still malleable, providing the most engineering freedom for environmental sustainability measures. Experience with this design at NSTM revealed that the preliminary stage was the most influential with respect to the overall consideration of environmental sustainability of the VIRMm2/3 train. The design of the framework reflects this by making the identification of improvement opportunities the first step of the preliminary study.

The second mechanism is the focus on improving the accessibility and (perceived) ease-of-use of processes for the inclusion of environmental sustainability, to empower engineers to make sustainability-focused decisions. This mechanism is especially relevant during earlier design stages, when uncertainty is highest. In the design of the framework, the DfE matrix and the 10 Golden rules of EcoDesign were selected based on their accessibility and ease-of-use. The evaluation of the framework at NSTM however, revealed that despite its overall usefulness, the framework also added complexity to the modernization process and required additional efforts to apply. This indicates that when integrating environmental sustainability in train modernization processes, there is a trade-off to be made between accessibility and the level of detail in which the complex and broad topic of environmental sustainability is taken into account.

The third mechanism of the framework design consists of the inclusion of environmental sustainability-related design goals and requirements. In this regard, a common saying summarizes this mechanism well: "If you cannot measure it, you cannot improve it". It is therefore crucial to use concrete goals and requirements and to treat these requirements in a similar way to existing requirements [50]. By evaluating the design of the premodernized train with respect to environmental sustainability, and comparing this to the goals of the railway organization (in this case, the parent company NS), clear improvement goals could be formulated and applied during the evaluation of the modernized train design. Furthermore, the use of these requirements also revealed that environmental sustainability is not easily captured in a single criterion. It is likely that many design decisions have dissimilar environmental sustainability impact trade-offs, where one alternative is better in one regard, but worse in another (as indicated in the seating option example). The use of quantitative requirements, such as the EcoBudgets, do not provide guidance to suggest which design should be preferred. Instead, they focus the discussion towards the question of which complete set of train design decisions best fits the overall design requirements. 


\section{Limitations, Recommendations and Future Research}

This article focused on the sustainability in the modernization of a train series intended for passenger transportation. Furthermore, the framework itself was designed to the needs of a single national railway operator. Even though the three aforementioned mechanisms are generalizable to similar application contexts, the exact EcoDesign principles and the alignment of the phases in the framework applied may therefore need to be slightly adapted to fit specific applications.

In the future, the usability of the designed framework can be further improved by digitally supporting the act of creating and communicating DfE matrices and EcoBudgets using ICT applications. Even though the use of LCA was deemed too unsuitable to be included in the design of the framework, further research is required on how, and to what extent, LCA can be effectively applied in the earliest design stages.

\section{Conclusions}

As environmental sustainability becomes more and more important to society, the transportation sector is also working to reduce its environmental impact. A review of recent trends in literature reveals that there are many approaches to improving environmental sustainability in this sector. Universally applicable environmental sustainability principles in this sector appear to focus on four main areas: (1) the elimination of hazardous materials and substances; (2) the use of design for disassembly, reuse, and remanufacture; (3) the optimization for energy efficiency; and (4) the use of LCA to facilitate more environmentally sustainable decision-making. Key questions for individual organizations are which of these universal principles to apply and how to implement them during engineering and design decision-making processes? This research focused on these questions for the process of train modernization, as this provides an interesting halfway point for the life cycle of a train series. During this midlife update, there is both room for improvement as well as sufficient information to base these improvement decisions on.

To this end, a framework was designed that is aimed at integrating environmental sustainability into existing train modernization processes. By designing and testing this framework in a real-world application context, a better understanding of the challenges and opportunities surrounding the consideration of environmental sustainability during train modernization projects could be developed. The main findings could be explained using three key design mechanisms: (a) Environmental sustainability should be considered as early as possible in the design process. (b) This requires efforts to simplify the way environmental sustainability principles and impacts are considered, while being careful not to oversimplify. Finally, (c) environmental sustainability impact is not a single aspect to be optimized for design decisions, but requires trade-offs between various environmental impact aspects for each design decision. The use of sustainability-focused design criteria and environmental impact budgets was demonstrated to be an effective way to facilitate this decision-making process at a Dutch railway operator. This stimulated the organization to decide to what extent various environmental factors are prioritized, both in the organizational goals as well as in design decisions.

Author Contributions: Conceptualization, A.M., W.H., and J.B.; methodology, W.H. and A.M.; validation, A.M., J.B., and W.H.; resources, L.v.D.; writing—original draft, W.H.; writing—review and editing, W.H., A.M., and J.B.; supervision, A.M. and J.D.; funding acquisition, J.B. and L.v.D.; All authors have read and agreed to the published version of the manuscript.

Funding: This research received no external funding.

Acknowledgments: The authors would like to thank the case company NS Trein Modernisering (NSTM) for their participation in this research. This article is based on the MSc graduation project findings of Ir. Dominick Viëtor.

Conflicts of Interest: The authors declare no conflicts of interest. 


\section{Appendix A}

Table A1. List of questions used in the DfE matrix for NSTM.

\begin{tabular}{|c|c|}
\hline \multicolumn{2}{|r|}{ Question } \\
\hline A1 & Are lightweight materials used in the train where possible? \\
\hline A2 & Have structural reinforcements for making parts more lightweight been considered? \\
\hline A3 & Is the train energy efficient according to current standards? \\
\hline A4 & $\begin{array}{l}\text { If possible, is energy regenerated in the train's systems and used in another system or fed back } \\
\text { to the catenary? }\end{array}$ \\
\hline A5 & Is friction in the train's systems or at the system boundaries minimized? \\
\hline A6 & Is electrical resistance in the systems minimized? \\
\hline A7 & Is a proper energy monitoring system installed and certified? \\
\hline A8 & $\begin{array}{l}\text { Is it possible to switch off systems when not in use? Is it possible to do this remotely or } \\
\text { automatically? }\end{array}$ \\
\hline B1 & Does the train use materials with low embedded GHG emissions? \\
\hline B1 & Are suppliers selected based on or encouraged in their energy conservation practices? \\
\hline $\mathrm{C} 1$ & Are the used components vandalism proof? \\
\hline $\mathrm{C} 2$ & Is environmental impact considered when choosing materials? \\
\hline $\mathrm{C} 3$ & Does the train use renewable materials when possible? \\
\hline $\mathrm{C} 4$ & Is the amount of material used by the system kept to a minimum? \\
\hline C5 & Is the amount of parts that are reused during modernization as high as possible? \\
\hline D1 & Are recycled materials used when possible? \\
\hline E1 & Are used materials easily recyclable at the end of their life cycle? \\
\hline E2 & Are used materials easily separated? \\
\hline E3 & Are components easily disassembled? \\
\hline E4 & Is the amount of different materials used kept to a minimum? \\
\hline E5 & Is recyclability of components demanded from suppliers? \\
\hline E6 & Are the origin and composition of materials well documented? \\
\hline F1 & Is information regarding recycling well documented? \\
\hline F2 & Are parts easy to source or reproduce, even years after production has ended? \\
\hline F3 & Is compatibility of components with other train series maximized? \\
\hline F4 & Are the train's systems designed to be easily repairable? \\
\hline F5 & Is the system architecture modular, so that damaged components can easily be exchanged? \\
\hline F6 & Is the train designed in such a way that the use of disposable components is avoided? \\
\hline F7 & Is the lifespan of the train's systems and their components optimized for the train life cycle? \\
\hline G1 & Is the train designed to minimize the use of lubricants, grease, and oils? \\
\hline G2 & Is the train designed to minimize the use of cleaning products? \\
\hline G3 & Does the train facilitate the use of nonhazardous cleaning products? \\
\hline G4 & $\begin{array}{l}\text { Is the train designed to minimize contact with and emission of harmful materials during } \\
\text { maintenance? }\end{array}$ \\
\hline G5 & Is the train designed to minimize the application and impact of graffiti? \\
\hline H1 & In case a hazardous substance is used, have alternatives been thoroughly investigated? \\
\hline H2 & In case a hazardous substance is used, is a closed material loop facilitated? \\
\hline
\end{tabular}


Table A1. Cont.

\begin{tabular}{|c|c|}
\hline \multicolumn{2}{|r|}{ Question } \\
\hline H3 & $\begin{array}{l}\text { Are suppliers selected based on or encouraged in their reduction of the use of hazardous } \\
\text { substances? }\end{array}$ \\
\hline H4 & Are wear-resistant materials used to avoid emissions from wear during use? \\
\hline H5 & $\begin{array}{l}\text { Are components that include hazardous substances isolated and protected from leakage and } \\
\text { corrosion? }\end{array}$ \\
\hline H6 & Is information regarding toxicity of the train well documented? \\
\hline I1 & Is discarded material from the old train $100 \%$ recycled or reused? \\
\hline I2 & $\begin{array}{l}\text { Are proper precautions taken to mitigate the effects of any spills of hazardous substances } \\
\text { during disassembly? }\end{array}$ \\
\hline J1 & Is the amount of energy used during manufacturing minimized? \\
\hline $\mathrm{J} 2$ & Is waste heat in manufacturing used for other processes? \\
\hline J3 & Is waste material from manufacturing minimized and when possible reused or recycled? \\
\hline J4 & Is a proper ventilation system for particulate matter in place in the manufacturing process? \\
\hline J5 & Does the manufacturing site use renewable energy for its processes and vehicles? \\
\hline K1 & Are components sourced as closely to the assembly site as possible? \\
\hline K2 & Is the logistics process optimized for as few truck movements as possible? \\
\hline K3 & Is the amount of packaging used to ship components minimized by suppliers? \\
\hline K3 & Is the same packaging used multiple times during the project? \\
\hline K4 & Is reused or recycled material used for the packaging? \\
\hline K5 & Is the number of unusable products kept to an absolute minimum? \\
\hline L1 & Does the train use any showcase environmental techniques? \\
\hline L2 & Does the train include features to stimulate its use over cars? \\
\hline L3 & Is the use of reused and recycled material visible in the train? \\
\hline L4 & Are the taken energy reduction or generation measures visible in the train? \\
\hline
\end{tabular}

\section{References}

1. Elkington, J. Cannibals With Forks: The Triple Bottom Line of 21st Century Business; Capstone Publishing: Oxford, UK, 1997; ISBN 190096127X.

2. Miller, P.; de Barros, A.G.; Kattan, L.; Wirasinghe, S.C. Public transportation and sustainability: A review. KSCE J. Civ. Eng. 2016, 20, 1076-1083. [CrossRef]

3. Eldeeb, G.; Mohamed, M. Understanding the transit market: A persona-based approach for preferences quantification. Sustainability 2020, 12, 3863. [CrossRef]

4. Eliasson, J.; Kopsch, F.; Mandell, S.; Wilhelmsson, M. Transport mode and the value of accessibility-a potential input for sustainable investment analysis. Sustainability 2020, 12, 2143. [CrossRef]

5. Stjernborg, V.; Mattisson, O. The role of public transport in society-A case study of general policy documents in Sweden. Sustainability 2016, 8, 1120. [CrossRef]

6. Goodland, R.; Daly, H. Environmental sustainability: Universal and non-negotiable. Ecol. Appl. 1996, 6, 1002-1017. [CrossRef]

7. Banister, D. Sustainable transport: Challenges and opportunities. Transportmetrica 2007, 3, 91-106. [CrossRef]

8. Wanke, P.; Chen, Z.; Zheng, X.; Antunes, J. Sustainability efficiency and carbon inequality of the Chinese transportation system: A robust bayesian stochastic frontier analysis. J. Environ. Manag. 2020, 260, 110163. [CrossRef]

9. Chen, S.; Wu, J.; Zong, Y. The impact of the freight transport modal shift policy on China's carbon emissions reduction. Sustainability 2020, 12, 583. [CrossRef] 
10. García-Olivares, A.; Solé, J.; Samsó, R.; Ballabrera-Poy, J. Sustainable European transport system in a $100 \%$ renewable economy. Sustainability 2020, 12, 5091. [CrossRef]

11. Lee, C.K.; Kim, Y.K.; Pruitichaiwiboon, P.; Kim, J.S.; Lee, K.M.; Ju, C.S. Assessing environmentally friendly recycling methods for composite bodies of railway rolling stock using life-cycle analysis. Transp. Res. Part D Transp. Environ. 2010, 15, 197-203. [CrossRef]

12. Thong, M.; Cheong, A. Energy efficiency in Singapore's rapid transit system. In Journeys: Sharing Urban Transport Solutions; LTA Academy: Singapore, 2012; pp. 38-47.

13. Powell, J.P.; González-Gil, A.; Palacin, R. Experimental assessment of the energy consumption of urban rail vehicles during stabling hours: Influence of ambient temperature. Appl. Therm. Eng. 2014, 66, 541-547. [CrossRef]

14. Azzouz, L.; Jack, A. Benchmarking the sustainability reporting of high-speed railways (HSRs): Towards a state-of-the-art benchmarking and reporting framework for HSRs. J. Clean. Prod. 2020, 250, 119505. [CrossRef]

15. Johansson, N.; Roth, E.; Reim, W. Smart and sustainable emaintenance: Capabilities for digitalization of maintenance. Sustainability 2019, 11, 3553. [CrossRef]

16. Manojlović, A.V.; Papić, V.D.; Filipović, S.M.; Jovanović, V.D. Fleet renewal: An approach to achieve sustainable road transport. Therm. Sci. 2011, 15, 1223-1236. [CrossRef]

17. Nicola, D.A.; Rosen, M.A.; Bulucea, C.A.; Brandusa, C. Some sustainability aspects of energy conversion in urban electric trains. Sustainability 2010, 2, 1389-1407. [CrossRef]

18. Ander, Å.; Bergendorff, M.; Carlson, R.; Dewulf, W.; Duflou, J.; Forsberg, P.; Gernez, L.; Glivberg, G.; Granholm-Thorén, A.; Grimadell, N.; et al. Integrating Eco-Efficiency in Rail Vehicle Design: Final Report of the RAVEL Project; Dewulf, W., Duflou, J., Ander, A., Eds.; Leuven University Press: Leuven, Belgium, 2001; ISBN 9058671763.

19. Överstam, U. Applying eco-design guidelines when designing rolling stock. In Proceedings of the 13th UIC Sustainability Conference, Vienna, Austria, 12-14 October 2016.

20. Ribeiro, J.S.; Gomes, J.D.O. A framework to integrate the end-of-life aircraft in preliminary design. Procedia CIRP 2014, 15, 508-513. [CrossRef]

21. Towle, I.; Johnston, C.; Lingwood, R.; Grant, P.S. The Aircraft at End of Life Sector: A Preliminary Study; Department of Materials, Oxford University: Oxford, UK, 2004.

22. Merkisz-Guranowska, A.; Merkisz, J.; Jacyna, M.; Pyza, D.; Stawecka, H. Rail vehicles recycling. WIT Trans. Built Environ. 2014, 135, 425-436. [CrossRef]

23. Kaewunruen, S.; Lee, C.K. Sustainability challenges in managing end-of-life rolling stocks. Front. Built Environ. 2017, 3, 10-12. [CrossRef]

24. Garnier de Falletans, T. Levers for recyclable trains. In Proceedings of the 13th UIC Sustainability Conference, Vienna, Austria, 12-14 October 2016.

25. Silva, R.F.; Kaewunruen, S. Recycling of rolling stock. Environments 2017, 39, 39. [CrossRef]

26. Hauschild, M.; Jeswiet, J.; Alting, L. From life cycle assessment to sustainable production: Status and perspectives. CIRP Ann. Manuf. Technol. 2005, 54, 1-21. [CrossRef]

27. Jajac, N.; Kilič, J.; Rogulj, K. An integral approach to sustainable decision-making within maritime spatial planning-A DSC for the planning of anchorages on the Island of Šolta, Croatia. Sustainability 2018, 11, 104. [CrossRef]

28. Cross, N. Designerly ways of knowing: Design discipline versus design science. Des. Issues 2001, 17, 49-55. [CrossRef]

29. van Aken, J.; Chandrasekaran, A.; Halman, J. Conducting and publishing design science research: Inaugural essay of the design science department of the Journal of Operations Management. J. Oper. Manag. 2016, 47-48, 1-8. [CrossRef]

30. Hevner, A.R. A three cycle view of design science research. Scand. J. Inf. Syst. 2007, 19, 87-92.

31. Wieringa, R.J. Design Science Methodology for Information Systems and Software Engineering; Springer: Berlin/Heidelberg, Germany, 2014; ISBN 978-3-662-43838-1.

32. Peffers, K.; Tuunanen, T.; Rothenberger, M.; Chatterjee, S. A design science research methodology for information systems research. J. Manag. Inf. Syst. 2007, 24, 45-77. [CrossRef]

33. Pigosso, D.C.A.; Zanette, E.T.; Filho, A.G.; Ometto, A.R.; Rozenfeld, H. Ecodesign methods focused on remanufacturing. J. Clean. Prod. 2010, 18, 21-31. [CrossRef] 
34. Rossi, M.; Germani, M.; Zamagni, A. Review of ecodesign methods and tools. Barriers and strategies for an effective implementation in industrial companies. J. Clean. Prod. 2016, 129, 361-373. [CrossRef]

35. Rousseaux, P.; Gremy-Gros, C.; Bonnin, M.; Henriel-Ricordel, C.; Bernard, P.; Floury, L.; Staigre, G.; Vincent, P. "Eco-tool-seeker"A new and unique business guide for choosing ecodesign tools. J. Clean. Prod. 2017, 151, 546-577. [CrossRef]

36. Bovea, M.D.; Pérez-Belis, V. A taxonomy of ecodesign tools for integrating environmental requirements into the product design process. J. Clean. Prod. 2012, 20, 61-71. [CrossRef]

37. Crul, M.R.M.; Diehl, J.C. Design for Sustainability: A Step-by-Step Approach; United Nations Environment Program: Paris, France, 2009; ISBN 92-807-2711-7.

38. Hauschild, M.; Wenzel, H.; Alting, L. Life cycle design-A route to the sustainable industrial culture? Ann. CIRP 1999, 48, 393-396. [CrossRef]

39. Luttropp, C.; Lagerstedt, J. EcoDesign and the ten golden rules: Generic advice for merging environmental aspects into product development. J. Clean. Prod. 2006, 14, 1396-1408. [CrossRef]

40. Lagerstedt, J. Functional and Environmental Factors in Early Phases of Product Development-Eco Functional Matrix. Ph.D. Thesis, KTH Royal Institute of Technology, Stockholm, Sweden, 24 January 2003.

41. Schöggl, J.P.; Baumgartner, R.J.; Hofer, D. Improving sustainability performance in early phases of product design: A checklist for sustainable product development tested in the automotive industry calls for papers-upcoming special issues and books on sustainable business models view project AKRosA. J. Clean. Prod. 2017, 140, 1602-1617. [CrossRef]

42. Yarwood, J.M.; Eagan, P.D. Design for the Environment: A Competitive Edge for the Future - Toolkit; Minnesota Office of Environmental Assistance: Minnesota, USA, 2001.

43. Mathieux, F.; Froelich, D.; Moszkowicz, P. ReSICLED: A new recovery-conscious design method for complex products based on a multicriteria assessment of the recoverability. J. Clean. Prod. 2008, 16, 277-298. [CrossRef]

44. Cerdan, C.; Gazulla, C.; Raugei, M.; Martinez, E.; Fullana-I-Palmer, P. Proposal for new quantitative eco-design indicators: A first case study. J. Clean. Prod. 2009, 17, 1638-1643. [CrossRef]

45. Duflou, J.R.; Dewulf, W. Eco-Impact Anticipation by Parametric Screening of Machine System Components: An introduction to the EcoPaS Methodology. In Product Engineering; Springer: Dordrecht, The Netherlands, 2004; pp. 17-30.

46. Umeda, Y.; Takata, S.; Kimura, F.; Tomiyama, T.; Sutherland, J.W.; Kara, S.; Herrmann, C.; Duflou, J.R. Toward integrated product and process life cycle planning-An environmental perspective. CIRP Ann. Manuf. Technol. 2012, 61, 681-702. [CrossRef]

47. Ryu, J.; Kim, I.; Kwon, E.; Hur, T. Simplified life cycle assessment for eco-design. In Proceedings of the EcoDesign 3rd International Symposium on Environmentally Conscious Design and Inverse Manufacturing, Tokyo, Japan, 8-11 December 2003; pp. 459-463.

48. Hauschild, M.Z. Introduction to LCA methodology. In Life Cycle Assessment: Theory and Practice; Hauschild, M.Z., Rosenbaum, R.K., Olsen, S.I., Eds.; Springer International Publishing: Cham, Switzerland, 2017; pp. 59-66. ISBN 9783319564753.

49. Priddy, R.D. Sustainability: The train has left the station. MRS Energy Sustain. 2017, 4, 1-10. [CrossRef]

50. Mahaux, M.; Heymans, P.; Saval, G. Discovering sustainability requirements: An experience report. In Proceedings of the International Working Conference on Requirements Engineering: Foundation for Software Quality, Essen, Germany, 28-30 March 2011; Springer: Berlin/Heidelberg, Germany, 2011; Volume 6606, pp. 19-33.

(C) 2020 by the authors. Licensee MDPI, Basel, Switzerland. This article is an open access article distributed under the terms and conditions of the Creative Commons Attribution (CC BY) license (http://creativecommons.org/licenses/by/4.0/). 